REFERENCES:

[1] McInnes IB, et al. Lancet. 2020; 395:1496-505.

Table 1. ACR Core Components at Week 52

\begin{tabular}{llll}
\hline Variables & Secukinumab $300 \mathrm{mg}$ & Adalimumab $40 \mathrm{mg}$ & $P$-value \\
& $(\mathrm{N}=426)$ & \multicolumn{2}{c}{$(\mathrm{N}=427)$} \\
\hline & $\mathrm{BL}$, mean & $\mathrm{LSM}$ change $\mathrm{BL}$, mean & $\mathrm{LSM}$ change \\
$\pm \mathrm{SE}$ & from $\mathrm{BL} \pm \mathrm{SE} \pm \mathrm{SE}$ & from $\mathrm{BL} \pm \mathrm{SE}$ \\
\hline
\end{tabular}

Tender joint score

$19.4 \pm 13.86-14.27 \pm 0.4420 .6 \pm 14.81-13.90 \pm 0.450 .5549$

(based on 78 joints)

Swollen joint score

$9.7 \pm 7.30 \quad-8.41 \pm 0.19 \quad 10.2 \pm 7.86 \quad-8.06 \pm 0.20 \quad 0.1962$

(based on 76 joints)

Patients global assessment $\quad 64.0 \pm 19.67-33.81 \pm 1.14 \quad 61.9 \pm 20.75-31.61 \pm 1.190 .1825$ Physicians global assessment60.0 $\pm 17.12-46.24 \pm 0.8061 .4 \pm 15.92-43.63 \pm 0.840 .0243$ Psoriatic arthritis pain (VAS) $58.6 \pm 23.49-30.21 \pm 1.1857 .9 \pm 22.42-29.44 \pm 1.230 .6500$ Erythrocyte sedimentation $\quad 23.8 \pm 18.93-9.63 \pm 0.62 \quad 23.9 \pm 17.99-9.28 \pm 0.64 \quad 0.7029$ rate $(\mathrm{mm} / \mathrm{h})$

LS mean and nominal $P$-values are from a mixed-effects repeated measures model with treatment group, analysis visit as factors, weight and BL score as covariates, and by treatment and $\mathrm{BL}$ score as interaction terms, unstructured covariance structure. ACR, American College of Rheumatology; BL, baseline; LSM, least squares mean; N, total number of randomised patients; SE, standard error; VAS, visual analogue scale

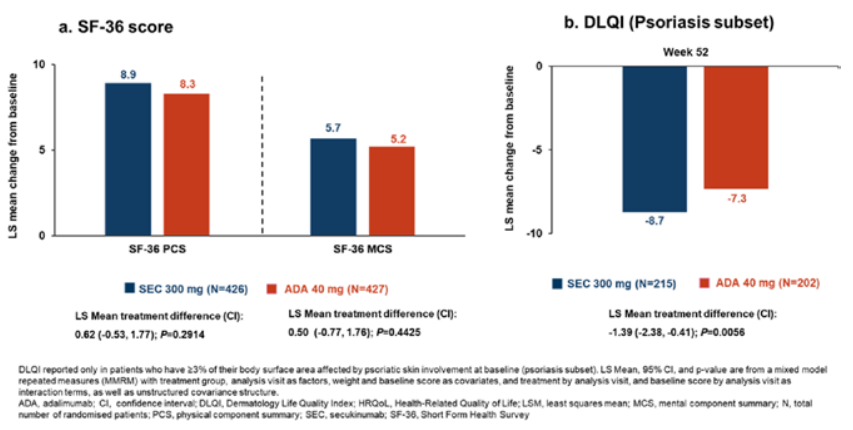

Figure 1. HRQoL Analysis at Week 52

Disclosure of Interests: Philippe Goupille Speakers bureau: AbbVie, Amgen, Biogen, BMS, Celgene, Chugai, Janssen, Eli Lilly, Medac, MSD, Nordic Pharma Novartis, Pfizer, Sanofi and UCB, Consultant of: AbbVie, Amgen, Biogen, BMS Celgene, Chugai, Janssen, Eli Lilly, Medac, MSD, Nordic Pharma, Novartis, Pfizer, Sanofi and UCB, Grant/research support from: AbbVie, Amgen, Biogen, BMS, Celgene, Chugai, Janssen, Eli Lilly, Medac, MSD, Nordic Pharma, Novartis, Pfizer, Sanofi and UCB, Frank Behrens Paid instructor for: Eli Lilly, Consultant of: Pfizer, AbbVie, Sanofi, Eli Lilly, Novartis, Genzyme, Boehringer Ingelheim, Janssen, MSD, Celgene, Roche and Chugai, Grant/research support from: Pfizer, Janssen, Chugai, Celgene and Roche, Laura C Coates Consultant of: AbbVie, Amgen, Boehringer Ingelheim, Biogen, BMS, Celgene, Domain, Eli Lilly, Gilead, GSK, Janssen, Medac, Novartis, Pfizer, Serac and UCB, Grant/research support from: AbbVie, Amgen, Celgene, Eli Lilly, Janssen, Novartis, Pfizer and UCB, Jord Gratacos-Masmitja Speakers bureau: AbbVie, Amgen, BMS, Celgene, Janssen, Eli Lilly, Novartis and Pfizer, Consultant of: AbbVie, Amgen, BMS, Celgene, Janssen, Eli Lilly, Novartis and Pfizer, Grant/research support from: AbbVie, Amgen, BMS, Celgene, Janssen, Eli Lilly, Novartis and Pfizer, Philip J Mease Speakers bureau: AbbVie, Amgen, Genentech, Janssen, Eli Lilly, Merck, Novartis, Pfizer, and UCB, Consultant of: AbbVie, Amgen, Bristol-Myers Squibb, Boehringer Ingelheim, Galapagos, Celgene, Genentech, Gilead, Janssen, Eli Lilly, Novartis, Pfizer, SUN Pharma, and UCB, Grant/research support from: AbbVie, Amgen, Bristol-Myers Squibb, Celgene, Galapagos, Genentech, Gilead, Janssen, Eli Lilly, Merck, Novartis, Pfizer, SUN Pharma, and UCB, Dafna D Gladman Consultant of: Amgen, AbbVie, BMS, Celgene, Eli Lilly, Gilead, Galapagos, Janssen, Novartis, Pfizer and UCB, Grant/research support from: Amgen, AbbVie, Celgene, Eli Lilly, Janssen, Novartis, Pfizer and UCB, Peter Nash Speakers bureau: Novartis, Abbvie, Roche, Pfizer, BMS, Janssen, Celgene, UCB, Eli Lilly, MSD, Sanofi, Gilead, Consultant of: Novartis, Abbvie, Roche, Pfizer, BMS, Janssen, Celgene, UCB, Eli Lilly, MSD, Sanofi, Gilead, Grant/research support from: Novartis, Abbvie, Roche, Pfizer, BMS, Janssen, Celgene, UCB, Eli Lilly, MSD, Sanofi, Gilead, Arthur Kavanaugh Consultant of: AbbVie, Amgen, Celgene, Eli Lilly, Janssen, Novartis, and UCB, Grant/research support from: AbbVie, Amgen, Celgene, Eli Lilly, Janssen, Novartis, and UCB, Ruvie Martin Shareholder of: Novartis, Employee of: Novartis, Weibin
Bao Shareholder of: Novartis, Employee of: Novartis, Corine Gaillez Shareholder of: Novartis and BMS, Employee of: Novartis, lain McInnes Speakers bureau: AbbVie, Amgen, Bristol-Myers Squibb, Celgene, Janssen, Eli Lilly, Novartis, Pfizer, and UCB, Consultant of: AbbVie, Amgen, Bristol-Myers Squibb, Celgene, Janssen, Eli Lilly, Novartis, Pfizer, and UCB, Grant/research support from: AbbVie, Amgen, Bristol-Myers Squibb, Celgene, Janssen, Eli Lilly, Novartis, Pfizer, and UCB. DOI: 10.1136/annrheumdis-2021-eular.1562

\section{POS1045 \\ IXEKIZUMAB EFFICACY ON SPINAL PAIN, DISEASE ACTIVITY AND QUALITY OF LIFE IN PATIENTS WITH PSORIATIC ARTHRITIS PRESENTING WITH SYMPTOMS SUGGESTIVE OF AXIAL INVOLVEMENT}

A. Deodhar ${ }^{1}$, D. D. Gladman ${ }^{2}$, R. Bolce ${ }^{3}$, D. Sandoval ${ }^{3}$, S. Y. Park ${ }^{3}$, S. Liu Leage $^{3}$, P. Nash ${ }^{4}$, D. Poddubnyy ${ }^{5} .{ }^{1}$ Oregon Health and Science University, School of Medicine, Oregon, United States of America; ${ }^{2}$ University of Toronto, Krembil Research Unit, Toronto, Canada; ${ }^{3}$ Eli Lilly and Company, Lilly Corporate Center, Indianapolis, United States of America; ${ }^{4}$ Griffith University, School of Medicine, Brisbane, Australia; ${ }^{5}$ Charité University Hospital, Department of Gastroenterology, Infectiology and Rheumatology, Berlin, Germany

Background: Many patients with psoriatic arthritis (PsA) experience back pain and stiffness, which may suggest axial involvement [1]. The prevalence of axial involvement in PsA varies between $25-70 \%$ [2]. Ixekizumab (IXE), a monoclonal antibody with high affinity for IL17-A, has been studied in Phase 3 trials in patients with PsA (SPIRIT-P1 [Biologic-naïve; NCT01695239] and SPIRIT-P2 [Inadequate response or intolerant to 1 or 2 TNF inhibitors (TNFi); NCT02349295]) [3] [4].

Objectives: To determine the efficacy of IXE up to 52 weeks (Wks) in reducing axial symptoms in patients with active PsA presenting with symptoms suggestive of axial involvement.

Methods: This post-hoc analysis included data from two subpopulations of patients with PsA (pooled SPIRIT-P1 and -P2). Symptoms suggestive of axial involvement were defined as Bath Ankylosing Spondylitis Disease Activity Index (BASDAI) Q2 (back pain) $\geq 4$, and an average of Q5 + Q6 (intensity and duration of morning stiffness in the spine) $\geq 4$ at baseline. Patients included in the sensitivity analysis subgroup 1 were, in addition to the above-mentioned overall analysis criteria, $<45$ years of age, while patients included in sensitivity analysis subgroup 2 were aged $<45$ but also had elevated C-reactive protein (CRP) $(>5 \mathrm{mg} / \mathrm{l})$ at baseline. Efficacy of IXE was analysed using BASDAI questions, total BASDAI, mBASDAI (without Q3), and Ankylosing Spondylitis Disease Activity Score (ASDAS) change from baseline, as well as BASDAI50 response and Short-Form-36 physical component summary (SF-36 PCS) improvement, at Wks 16, 24 and 52. Treatment comparison was done using logistic regression for BASDAI50, and analysis of covariance (ANCOVA) model for other endpoints. Missing data for binary and continuous endpoints were imputed by non-responder imputation and modified baseline observation carried forward (mBOCF), respectively. Results: A total of 313 patients (placebo (PBO), $N=151$; IXE Q4W, $N=162$ ) me the overall analysis inclusion criteria. Baseline values for BASDAI and ASDAS related endpoints were balanced across treatment arms (Table 1). Improvement in axial symptoms were significantly greater in patients treated with IXE compared to PBO at Wks 16 and 24 (Figure 1. next page) Improvement in quality of life (QoL) measures (SF-36 PCS) were also significantly greater in patients treated with IXE compared to PBO at Wks 16 and 24 (Table 1). Similar results were observed for patients $<45$ years, and in patients $<45$ years with CRP $>$ $5 \mathrm{mg} / \mathrm{l}$ at baseline (sensitivity analysis, data not shown).

Conclusion: IXE is effective in reducing axial symptoms and improving QoL in patients with active PsA presenting with symptoms suggestive of axial involvement.

Table 1. Baseline values and change from baseline (mBOCF) in the overall analysis population at Wks 16, 24 and 52 for BASDAl and ASDAS related endpoints in patients with PsA and axial pain. Data presented as mean (SD) unless otherwise specified. $\neq \mathrm{p}<0.001$ vs PBO.

\begin{tabular}{|c|c|c|c|c|c|}
\hline & $\begin{array}{l}\text { PBO } \\
(\mathrm{N}=151)\end{array}$ & & $\begin{array}{l}\text { IXE Q4W } \\
(\mathrm{N}=162)\end{array}$ & & \\
\hline Baseline values & Wk 0 & & Wk 0 & & \\
\hline BASDAI & $6.7(1.4)$ & & $6.6(1.3)$ & & \\
\hline Q2 & $7.0(1.7)$ & & $6.7(1.7)$ & & \\
\hline Q5 & $7.3(1.5)$ & & $7.3(1.5)$ & & \\
\hline Q6 & $5.8(2.7)$ & & $5.5(2.7)$ & & \\
\hline mBASDAI & $6.7(1.4)$ & & $6.6(1.3)$ & & \\
\hline ASDAS & $3.7(0.8)$ & & $3.6(0.9)$ & & \\
\hline SF-36 PCS & $29.9(7.4)$ & & $30.0(8.4)$ & & \\
\hline Outcome measures & Wk 16 & Wk 24 & Wk 16 & Wk 24 & Wk 52 \\
\hline ASDAS & $-0.4(0.8)$ & $-0.4(0.8)$ & $-1.2(1.2) \ddagger$ & $-1.3(1.2) \ddagger$ & $-1.4(1.2)$ \\
\hline BASDAI50, n (\%) & $16(11)$ & $12(8)$ & $51(32) \ddagger$ & 61 (38)‡ & $64(40)$ \\
\hline mBASDAI & $-1.0(1.7)$ & $-1.0(1.7)$ & $-2.1(2.1) \ddagger$ & $-2.4(2.3) \ddagger$ & $-2.7(2.1)$ \\
\hline SF-36 PCS & 1.9 (7.3) & $2.0(6.9)$ & $5.8(8.8) \ddagger$ & $6.8(9.9) \ddagger$ & $8.8(9.5)$ \\
\hline
\end{tabular}




\section{REFERENCES:}

[1] Yap KS. Ann Rheum Dis. 2018;77(11)

[2] Feld J. Nat Rev Rheumatol. 2018;14

[3] Orbai A. Clin Exp Rheumatol. 2020[online]

[4] Genovese MC. Rheumatol. 2018;57(11)

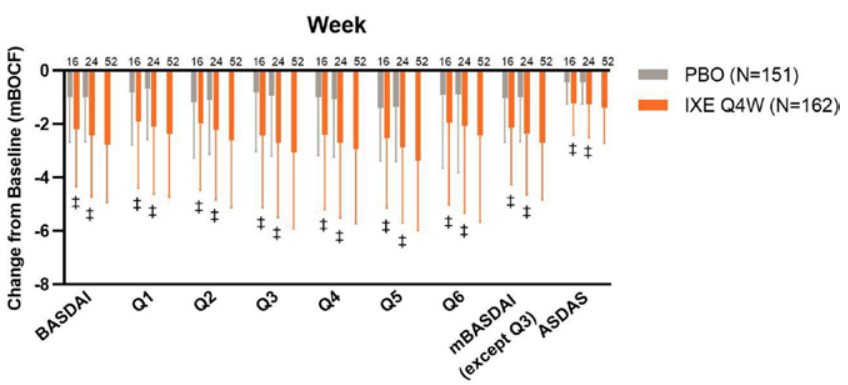

Figure 1. Change from baseline (mBOCF) in BASDAI and ASDAS related endpoints in patients with PsA and axial pain in the overall analysis population. Data presented as mean (SD). $\neq p<0.001$ vs PBO

Acknowledgements: Edel Hughes, an employee of Eli Lilly and Company, provided editorial and writing support.

Disclosure of Interests: Atul Deodhar Speakers bureau: Janssen, Novartis, Pfizer, Paid instructor for: Boeheringer Ingelheim, Pfizer, Consultant of: AbbVie, Amgen, Boeheringer Ingelheim, Bristol Myers Squibb, Celgene, Eli Lilly, Galapagos, Glaxo Smith Kline, Janssen, Novartis, Pfizer, UCB, Grant/research support from: AbbVie, Eli Lilly, Glaxo Smith Kline, Novartis, Pfizer, UCB, Dafna D Gladman Consultant of: Abbvie, Amgen, BMS, Galapagos, Gilead, Eli Lilly, Janssen, Novartis, Pfizer, UCB, Grant/research support from: Abbvie, Amgen, Eli Lilly, Janssen, Novartis, Pfizer, UCB, Rebecca Bolce Shareholder of: Employee and shareholder of Eli Lilly and Company, Employee of: Employee and shareholder of Eli Lilly and Company, David Sandoval Shareholder of: Eli Lilly and Company, Employee of: Currently employed by Eli Lilly and Company, So Young Park Shareholder of: Eli Lilly \& Company, Employee of: Eli Lilly \& Company, Soyi Liu Leage Shareholder of: Owns Lilly shares (company producing drug/devices for use in rheumatology), Employee of: Employee of Eli Lilly and Company, Peter Nash Speakers bureau: Honoraria for lectures on behalf Abbvie, BMS, Celgene, Roche, Sanofi, Lilly, Novartis, Janssen, Pfizer, Boehringer, Samsung, Consultant of: Advice on behalf Abbvie, BMS, Celgene, Roche, Sanofi, Lilly, Novartis, Janssen, Pfizer, Boehringer, Samsung, Grant/ research support from: Research funding for clinical trials on behalf Abbvie, BMS, Celgene, Roche, Sanofi, Lilly, Novartis, Janssen, Pfizer, Boehringer, Samsung, Denis Poddubnyy Speakers bureau: AbbVie, Bristol-Myers Squibb, Lilly, MSD, Novartis, Pfizer, and UCB, Consultant of: AbbVie, Biocad, Gilead, GlaxoSmithKline, Eli Lilly, MSD, Novartis, Pfizer, Samsung Bioepis, and UCB, Grant/research support from: AbbVie, Eli Lilly, MSD, Novartis, and Pfizer. DOI: 10.1136/annrheumdis-2021-eular.1570

\section{POS1046 IMPROVEMENTS IN PATIENT-REPORTED IMPACT OF PSORIATIC ARTHRITIS WITH IL-12/23 (USTEKINUMAB) OR TUMOUR NECROSIS FACTOR INHIBITORS: 1-YEAR DATA FROM THE LARGE, REAL-WORLD PSABIO STUDY}

L. Gossec ${ }^{1,2}$, S. Siebert ${ }^{3}$, P. Bergmans ${ }^{4}$, K. De Vlam ${ }^{5}$, E. Gremese ${ }^{6}$, B. Joven-lbáñez ${ }^{7}$, T. Korotaeva ${ }^{8}$, W. Noel $^{9}$, M. Nurmohamed ${ }^{10}$, P. Sfikakis ${ }^{11}$ E. Theander ${ }^{12}$, J. S. Smolen ${ }^{13}$. ${ }^{1}$ Sorbonne University, INSERM, Pierre Louis Institute of Epidemiology and Public Health, Paris, France; ${ }^{2}$ PitiéSalpêtrière Hospital, AP-HP, Department of Rheumatology, Paris, France; ${ }^{3}$ University of Glasgow, Institute of Infection, Immunity and Inflammation, Glasgow, United Kingdom; ${ }^{4}$ Janssen-Cilag BV, Biostatistics, Breda, Netherlands; ${ }^{5}$ University Hospitals Leuven, Division of Rheumatology, Leuven, Belgium; ${ }^{6}$ Catholic University of the Sacred Heart, Fondazione Policlinico A Gemelli-IRCCS, Rome, Italy; ${ }^{7}$ University Hospital 12 de Octubre, Department of Rheumatology, Madrid, Spain; ${ }^{8}$ VA Nasonova Research Institute of Rheumatology, Department of Spondyloarthritis and Psoriatic Arthritis, Moscow, Russian Federation; ${ }^{9}$ Janssen Pharmaceutica NV, Medical Affairs, Beerse, Belgium; ${ }^{10}$ Reade and VU University Medical Center, Department of Rheumatology, Amsterdam, Netherlands; ${ }^{11}$ National and Kapodistrian University of Athens Medical School, First Department of Propaedeutic and Internal Medicine, Athens, Greece; ${ }^{12}$ Janssen-Cilag $A B$, Medical Affairs, Solna, Sweden; ${ }^{13}$ Medical University of Vienna,
Division of Rheumatology, Department of Medicine III, Vienna, Austria

Background: Psoriatic arthritis (PsA) negatively impacts patients' (pts) quality of life (QoL), with a high burden of pain, fatigue and psychological distress. The 12-item Psoriatic Arthritis Impact of Disease questionnaire (PSAID-12) is a validated measure of pt-reported disease impact.

Objectives: To analyse PsAID-12 score changes in the overall population and specific subgroups of interest, and assess correlation of these changes using Health Assessment Questionnaire Disability Index (HAQ-DI).

Methods: PsABio (NCT02627768) is a multinational, prospective, observational study in pts with PsA receiving ustekinumab (UST) or a tumour necrosis factor inhibitor (TNFi) as a 1st/2nd/3rd-line biologic. Descriptive statistics, including $95 \% \mathrm{Cl}$, are presented at baseline $(\mathrm{BL})$ and 1 year. Linear regression, including propensity score (PS) adjustment for $\mathrm{BL}$ covariates, was used to compare change in PSAID-12 total from BL to 1 year between treatments. The relationship between changes in PSAID-12 and HAQ-DI was investigated using Spearman's correlation.

Results: Data were available for 438 UST and 455 TNFi pts. From BL to 1 year, significant improvements were seen in total PSAID-12 scores and in all domains with both treatments (Figure 1). PS-adjusted treatment comparison showed no difference in total PSAID-12 improvement (regression coefficient [95\% Cl]: $0.14[-0.22 ; 0.51], p=0.4433)$, or in any domain, except skin problems, which improved significantly more with UST than TNFi $(-0.55[-1.04$ -0.06], $p=0.0277$ ). Improvements in PSAID-12 and HAQ-DI showed strong positive correlation with both treatments (UST: $r=0.63, p<0.0001$; TNFi: $r=0.70, p<0.0001)$. Effectiveness was demonstrated with UST and TNFi in subgroups of interest, including biologic treatment line, sex and psoriasis extent (Table 1. next page).

Conclusion: Treatment with IL-12/23 (UST) or TNF inhibitors significantly improved pt-reported disease impact at 1 year. PS-adjusted PSAID-12 improvements did not differ significantly between treatments, except skin problems (better with UST). Improvements in disease impact and physical functioning (HAQ-DI) were strongly correlated, emphasising the effect of these biologics on QoL in PsA pts.

\section{Mean PsAID-12 overall and domain scores at baseline and 1 year with UST and TNFi}

UST: mean $(95 \% \mathrm{CI})$ PSAID-12 total score improved significantly from $5.75(5.54 ; 5.97)$ at BL to $3.68(3.43 ; 3.93)$ at 1 year

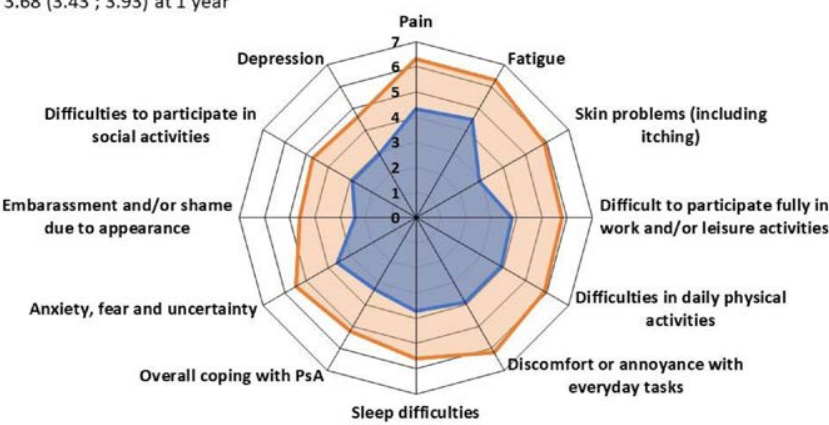

TNFI: mean $(95 \% \mathrm{CI})$ PsAID-12 total score improved significantly from $5.47(5.25 ; 5.69)$ at BL to $3.13(2.89 ; 3.38)$ at 1 year

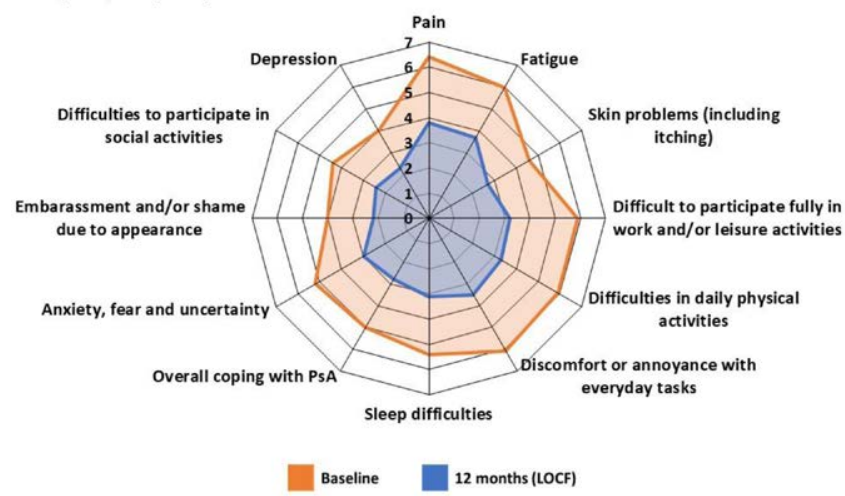

Figure 1. 